\title{
Microarray Data Analysis of Perturbed Pathways in Breast Cancer Tissues
}

\section{Changsik Kim, Jiwon Choi and Sukjoon Yoon*}

Department of Biological Sciences, Research Center for Women's Diseases (RCWD), Sookmyung Women's University, Seoul 140-742, Korea

\begin{abstract}
Due to the polygenic nature of cancer, it is believed that breast cancer is caused by the perturbation of multiple genes and their complex interactions, which contribute to the wide aspects of disease phenotypes. A systems biology approach for the identification of subnetworks of interconnected genes as functional modules is required to understand the complex nature of diseases such as breast cancer. In this study, we apply a 3-step strategy for the interpretation of microarray data, focusing on identifying significantly perturbed metabolic pathways rather than analyzing a large amount of overexpressed and underexpressed individual genes. The selected pathways are considered to be dysregulated functional modules that putatively contribute to the progression of disease. The subnetwork of protein-protein interactions for these dysregulated pathways are constructed for further detailed analysis. We evaluated the method by analyzing microarray datasets of breast cancer tissues; i.e., normal and invasive breast cancer tissues. Using the strategy of microarray analysis, we selected several significantly perturbed pathways that are implicated in the regulation of progression of breast cancers, including the extracellular matrix-receptor interaction pathway and the focal adhesion pathway. Moreover, these selected pathways include several known breast cancer-related genes. It is concluded from this study that the present strategy is capable of selecting interesting perturbed pathways that putatively play a role in the progression of breast cancer and provides an improved interpretability of networks of protein-protein interactions.
\end{abstract}

Keywords: breast cancer, microarray, metabolic pathways, protein-protein interactions, systems biology

*Corresponding author: E-mail yoonsj@sookmyung.ac.kr Tel +82-2-710-9415, Fax +82-2-2077-7322

Accepted 21 November 2008

\section{Introduction}

Microarray experiments have been a popular approach for identifying marker genes that are related to the progression of disease by providing insights into genome-wide gene expression data. Conventional analysis of microarray data has focused on finding significantly overexpressed and underexpressed genes as putative markers of disease. This has been useful in discriminating the roles of various individual genes in the progression of disease and in correlating dissected expression signatures with clinical outcomes (Dhanasekaran et al., 2001; Beer et al., 2002; van't Veer et al., 2002; Glinsky et al., 2004). However, comparing expression data between normal and diseased conditions can typically yield thousands of genes that are differentially expressed between the conditions with a statistical confidence $(p<0.05)$ (Dhanasekaran et al., 2001). That is, the conventional method may not be sufficient to narrow down the target pathways and genes for discriminating disease states, because only a few significantly dysregulated candidates genes can be studied in detail at any given moment. Moreover, most proteins are known to mediate their functions within regulated complex networks or pathways of interconnected macromolecules by forming dynamic topological interactomes. Additionally, genes that are not significantly altered may play a critical role with other significantly dysregulated components in their biological pathways. Therefore, a systems biology approach that can identify pathways with these proteins would significantly improve the ability to find disease-associated genes from micorarray datasets. This also would be useful in understanding the relationship between pathways and various phenotypes.

There has been a tremendous increase in information for constructing large-scale protein-protein interaction networks from public interactome databases, such as HPRD (Peri et al., 2004). A number of approaches have been demonstrated for identifying subnetworks of protein-protein interactions, based on coherent expression patterns of their genes (Chen and Yuan, 2006; Chuang et al., 2007). There also is a study that has identified candidate genes that are related to certain diseases based only on the topological features of the network of disease-related protein-protein interactions (Hwang et al., 2008). Recently, several methods for integrating microarray data with metabolic pathways have been pre- 
sented (Setlur et al., 2007; Grosu et al., 2008). None of these approaches has mapped transcriptional changes in both metabolic pathways and protein-protein interactions. Moreover, protein-protein interaction networks have very complex topological characteristics that sometimes impose difficulties in interpretation. Therefore, it will be convenient for the interpretation if the functional modules that have significantly perturbed genes are first identified to construct a subnetwork of protein-protein interactions in each functional module. It is believed that these subnetworks of protein-protein interactions in each functional module will provide greater interpretability than the genome-wide network of protein-protein interactions. Based on these points of view, we applied 3 steps of microarray data analysis. First, differentially expressed genes were selected using the standard t test. Second, significantly perturbed metabolic pathways were selected based on those differentially expressed genes. A test for the statistical significance of the selected pathways also is presented in this study. Third, subnetworks of protein-protein interactions in those perturbed metabolic pathways were constructed for further interpretation of pathways in detail.

Breast cancer is one of many complex progressive diseases. Due to its polygenic nature, it is believed that breast cancer is caused not by single genes but rather by perturbations of multiple genes and their complex interactions, which contribute to the wide aspects of disease phenotypes. Therefore, we apply the strategy of microarray analysis using the "score of perturbation" to identify significantly perturbed pathways. To this end, we identified significantly perturbed pathways in breast cancer tissues, thereby providing interesting pathways that putatively play roles in the progression of breast cancer. Furthermore, we constructed a subnetwork of protein-protein interactions in these significantly perturbed pathways for further interpretation of pathways in detail.

\section{Methods}

We used the dataset from Turashvili et al. (2007), which consists of 2 types of breast cancer tissues; i.e, invasive lobular and ductal carcinomas. This dataset includes a total of 30 samples that consist of normal ductal cells from 10 patients, normal lobular cells from 10 patients, invasive ductal carcinoma cells from 5 patients, and invasive lobular carcinoma cells from 5 patients, which were microdissected from cryosections of 10 mastectomy specimens from postmenopausal patients. In this dataset, 50 nanograms of total RNA was amplified and labeled by PCR and in vitro transcription, and samples were analyzed using Affymetrix U133 Plus 2.0 Arrays.
Pathways from KEGG (http://www.genome.jp/kegg/pathway.html) databases were used as pathway references for analysis.

The basic idea of our approach is to identify perturbed pathways that have relatively large amounts of overexpressed or underexpressed genes. To begin, a $p$ value that is calculated from the standard t test is assigned to every gene in each pathway, and the number of significantly perturbed genes $(p<0.01)$ is counted in each pathway. Note that the $t$ test for each gene is conducted by comparing 2 mean values of gene expression between 20 samples of normal breast cancer cells and 10 samples of invasive cancer cells. The score of perturbation for each pathway is assigned with the probability that we can, by chance, expect at least the same number of significantly perturbed genes in each pathway, given the number of significantly perturbed genes in the background set of genes. This probability is calculated using the cumulative hypergeometric distribution as follows:

$$
P(x, r, n, N)=\sum_{i=x}^{\min (r, n)} \frac{\left(\begin{array}{l}
r \\
i
\end{array}\right)\left(\begin{array}{c}
N-r \\
n-i
\end{array}\right)}{\left(\begin{array}{l}
N \\
n
\end{array}\right)}
$$

where $n$ is the number of genes in each pathway, $N$ the number of genes in whole pathways, $x$ the number of significantly perturbed genes in each pathway, and $r$ is the number of significantly perturbed genes in whole pathways. The pathways that have $p<0.01$ are selected as significantly perturbed genes in breast cancer tissues.

\section{Results and Discussion}

To explore perturbed pathways in breast cancer tissues, we analyzed the microarray dataset from Turashvilli et al. (2007), which was downloaded from the NCBI GEO (http://www.ncbi.nlm.nih.gov/geo/) database. The dataset was standardized such that each sample array has a mean of 0 and a standard deviation of 1 . The dataset contains samples of 2 breast cancer tissues and their corresponding normal cells. The standard t test was used to score genes for overexpression or underexpression in breast cancer tissues in comparison with their normal tissues. The list of significantly perturbed genes $(p<0.01)$ was classified into known biological pathways to select target pathways that are perturbed in breast cancer tissues, as described in Methods. As a result, it was found that 36 pathways were significantly perturbed, based on the score of perturbation $(p<0.01)$ in breast cancer tissues (see Supplementary Table $\mathbf{S 1}$ ).

Table 1 shows 36 significantly perturbed pathways, 
Table 1. Top 36 perturbed pathways in which component genes are significantly perturbed $(p<0.01)$ in breast cancer tissues

\begin{tabular}{|c|c|c|c|c|c|}
\hline Pathway & N1 & N2 & N3 & N4 & N5 \\
\hline Focal adhesion & 199 & 19 & 16 & 35 & $5.08 \mathrm{E}-17$ \\
\hline Cell junctions & 134 & 12 & 17 & 29 & $1.09 \mathrm{E}-16$ \\
\hline ECM-receptor interaction & 87 & 15 & 7 & 22 & $2.44 \mathrm{E}-14$ \\
\hline Systemic lupus erythematosus & 125 & 23 & 1 & 24 & $1.05 \mathrm{E}-12$ \\
\hline Regulation of actin cytoskeleton & 217 & 11 & 14 & 25 & $2.91 \mathrm{E}-08$ \\
\hline Axon guidance & 129 & 8 & 7 & 15 & $1.94 \mathrm{E}-05$ \\
\hline Prostate cancer & 91 & 6 & 6 & 12 & $3.91 \mathrm{E}-05$ \\
\hline Drug metabolism - cytochrome P450 & 67 & 2 & 8 & 10 & $6.05 \mathrm{E}-05$ \\
\hline Colorectal cancer & 85 & 3 & 8 & 11 & $9.90 \mathrm{E}-05$ \\
\hline Cytokine-cytokine receptor interaction & 273 & 7 & 14 & 21 & 0.00023 \\
\hline p53 signaling pathway & 68 & 4 & 5 & 9 & 0.000365 \\
\hline Cell cycle & 115 & 9 & 3 & 12 & 0.000384 \\
\hline Cell adhesion molecules (CAMs) & 132 & 7 & 6 & 13 & 0.000388 \\
\hline Renal cell carcinoma & 69 & 5 & 4 & 9 & 0.000408 \\
\hline Melanoma & 71 & 5 & 4 & 9 & 0.000506 \\
\hline Glutathione metabolism & 47 & 1 & 6 & 7 & 0.000812 \\
\hline Metabolism of xenobiotics by cytochrome P450 & 65 & 2 & 6 & 8 & 0.001268 \\
\hline Leukocyte transendothelial migration & 116 & 7 & 4 & 11 & 0.001501 \\
\hline alpha-Linolenic acid metabolism & 17 & 1 & 3 & 4 & 0.002006 \\
\hline Toll-like receptor signaling pathway & 104 & 7 & 3 & 10 & 0.002214 \\
\hline Small cell lung cancer & 87 & 5 & 4 & 9 & 0.002215 \\
\hline Bladder cancer & 42 & 4 & 2 & 6 & 0.002405 \\
\hline Pancreatic cancer & 73 & 5 & 3 & 8 & 0.002697 \\
\hline MAPK signaling pathway & 269 & 5 & 13 & 18 & 0.003258 \\
\hline Vibrio cholerae infection & 60 & 4 & 3 & 7 & 0.003474 \\
\hline Adherens junction & 76 & 3 & 5 & 8 & 0.003477 \\
\hline Tight junction & 135 & 3 & 8 & 11 & 0.004968 \\
\hline Glioma & 65 & 4 & 3 & 7 & 0.005453 \\
\hline GnRH signaling pathway & 100 & 5 & 4 & 9 & 0.005691 \\
\hline Biosynthesis of unsaturated fatty acids & 23 & 1 & 3 & 4 & 0.00639 \\
\hline PPAR signaling pathway & 68 & 2 & 5 & 7 & 0.006989 \\
\hline Nitrogen metabolism & 24 & 1 & 3 & 4 & 0.007472 \\
\hline Complement and coagulation cascades & 69 & 2 & 5 & 7 & 0.007566 \\
\hline TGF-beta signaling pathway & 87 & 4 & 4 & 8 & 0.007923 \\
\hline Non-small cell lung cancer & 54 & 4 & 2 & 6 & 0.008535 \\
\hline Neurodegenerative diseases & 39 & 2 & 3 & 5 & 0.008856 \\
\hline
\end{tabular}

Note that $N 1$ represents the total number of genes in each pathway, $N 2$ is the number of overexpressed genes $(p<0.01)$ in each pathway, $N 3$ is the number of underexpressed genes $(p<0.01)$ in each pathway, $N 4$ is the total number of significantly perturbed genes in each pathway (i.e., $N 4=N 2+N 3$ ), and $N 5$ is the score of perturbation; i.e., p-values by the cumulative hypergeometric distribution.

including Cell Junctions (Fig. 1), the ECM-receptor interaction pathway (Fig. 2), the Focal Adhesion pathway (Fig. 3), and the p53 signaling pathway, which have been implicated to play a role in the progression of breast cancers (Behmoaram et al., 2008; Fata et al., 2004; Lin et al., 2000; Ryan et al., 2000). It is well known that most cancers lack active tumor suppressor p53, which inhibits cell growth through activation of cell cycle arrest and apoptosis and that the activation of NFKB1 is induced by p53 (Ryan et al., 2000).

There are significant amounts of evidence that the ECM-receptor pathway is related to the progression of breast cancer. For instance, Fata et al. (2004) reviewed considerable research that indicated that mammary gland branching morphogenesis is dependent, in part, on the ECM; ECM-receptors, such as integrins and other ECM receptors; and ECM-degrading enzymes, including matrix metalloproteinases (MMPs) and their inhibitors, tissue inhibitors of metalloproteinases (TIMPs). They also provided some evidence that these ECM processes affect 1 or more of the following processes: cell survival, polarity, proliferation, differentiation, adhesion, and migration.

It is well known that breast carcinoma most often is 


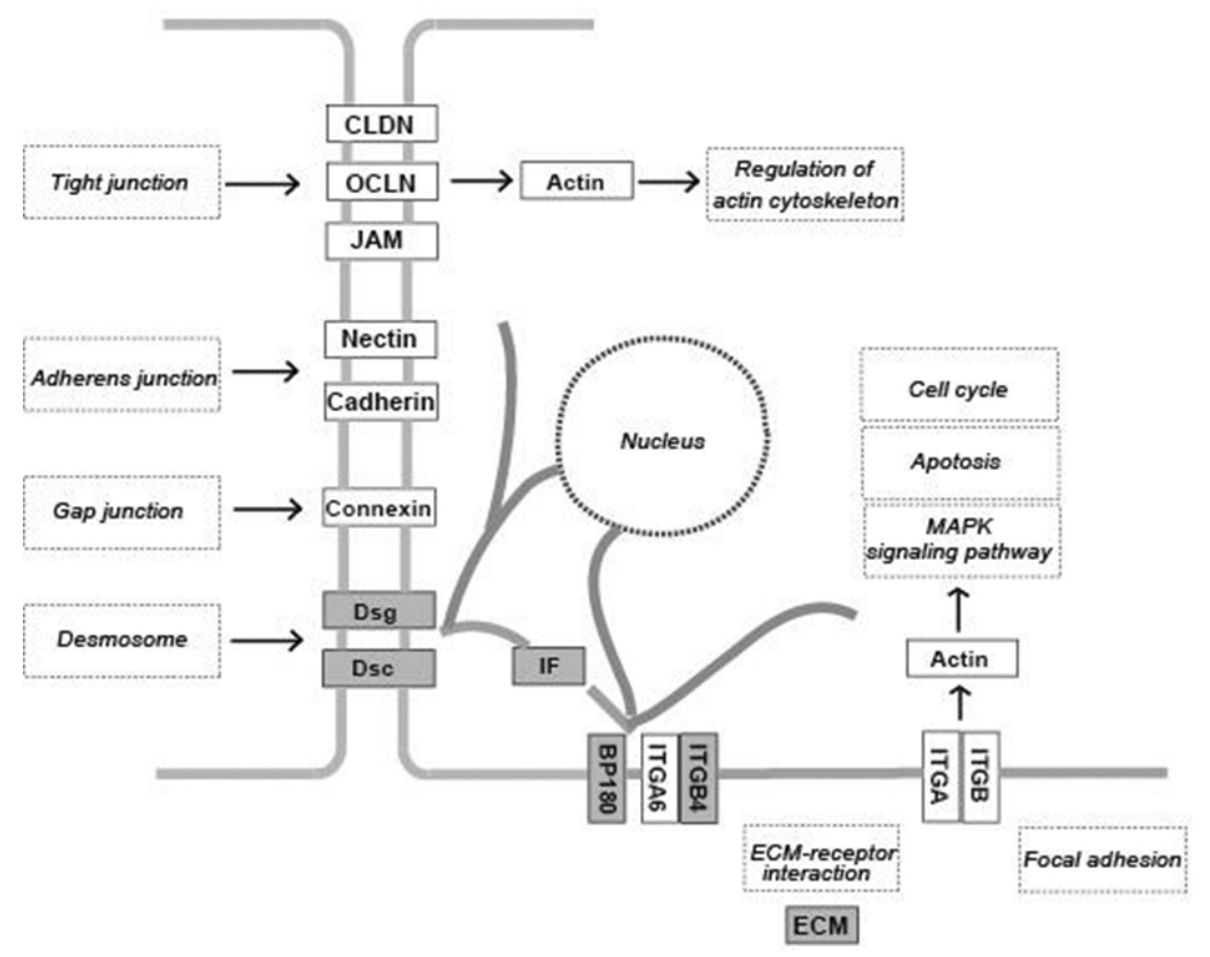

Fig. 1. Summary of the Cell Junctions pathway from the KEGG (http://www.genome.jp/kegg) database. Grey-colored boxes represent protein complexes with at least 1 significantly perturbed protein $(p<0.01)$ in breast cancer tissues. Note that the list of perturbed genes is tabulated in Table 2.

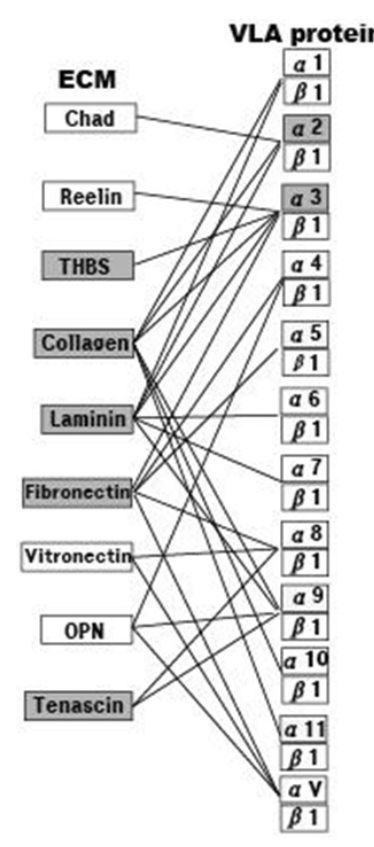

associated with an extensive 'stromal reaction', termed desmoplasia, in which excess collagen is deposited (Fata et al., 2004). It also has been shown that aberrations in the integrity, deposition, and composition of the ECM often are associated with breast cancer (Lochter and Bissell, 1995; Petersen et al., 2001).

In addition, upregulation of expression of the fibrillar
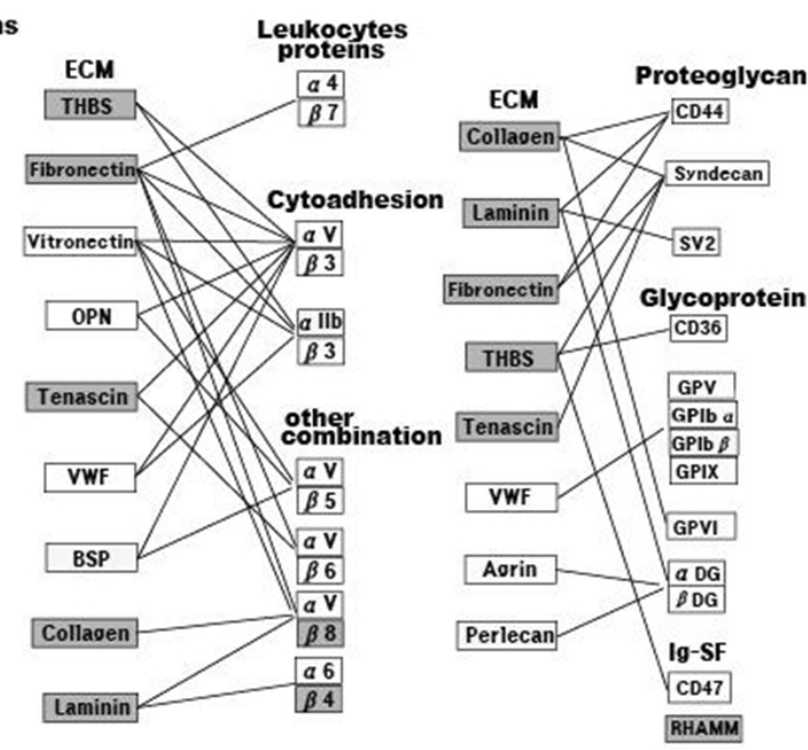

Fig. 2. Summary of the ECM-receptor Interaction pathway from the KEGG (http://www.genome.jp/ kegg) database. Grey-colored boxes represent protein complexes with at least 1 significantly perturbed protein $(p<0.01)$ in breast cancer tissues. Note that the list of perturbed genes is tabulated in Table 2.

collagen gene is an indicator of the metastatic phenotype (van't Veer et al., 2002; van de Vijver et al., 2002; Wang et al., 2002). The ECM and its receptors that attenuate or augment signaling regulate branching morphogenesis in a process that may be considered as controlled invasion. For instance, it has been shown that increased collagen type I upregulates activated MMP 2 


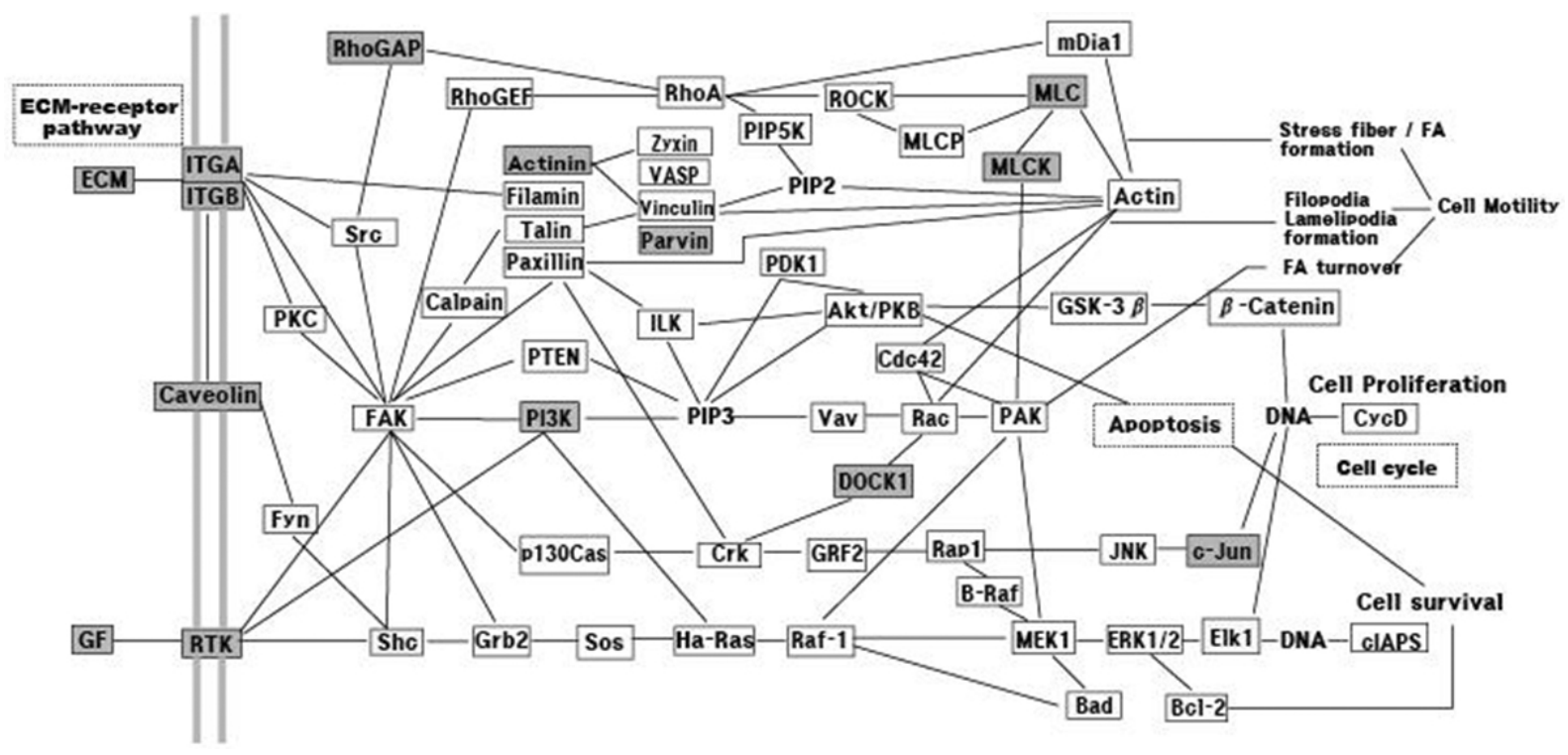

Fig. 3. Summary of the Focal Adhesion pathway from the KEGG (http://www.genome.jp/kegg) database. Grey-colored boxes represent protein complexes with at least 1 significantly perturbed protein $(p<0.01)$ in breast cancer tissues. Note that the list of perturbed genes is tabulated in Table 2.

Table 2. List of significantly perturbed genes $(\mathrm{p}<0.01)$ in the Cell Junctions, ECM-receptor interactions, and Focal Adhesion pathways

\begin{tabular}{|c|c|c|c|c|c|c|c|}
\hline Genes & Path1 & Path2 & Path3 & Genes & Path1 & Path2 & Path3 \\
\hline COL11A1 & $\triangle$ & $\triangle$ & $\triangle$ & KRT16 & $\nabla$ & & \\
\hline COL1A1 & $\triangle$ & $\triangle$ & $\triangle$ & KRT17 & $\nabla$ & & \\
\hline COL1A2 & $\triangle$ & $\triangle$ & $\triangle$ & KRT23 & $\nabla$ & & \\
\hline COL3A1 & $\triangle$ & $\triangle$ & $\triangle$ & KRT5 & $\nabla$ & & \\
\hline COL4A1 & $\triangle$ & $\triangle$ & $\triangle$ & KRT6B & $\nabla$ & & \\
\hline COL5A1 & $\triangle$ & $\triangle$ & $\triangle$ & KRT7 & $\nabla$ & & \\
\hline COL5A2 & $\triangle$ & $\triangle$ & $\triangle$ & KRT81 & $\nabla$ & & \\
\hline COL6A1 & $\triangle$ & $\triangle$ & $\triangle$ & FNDC1 & & $\triangle$ & \\
\hline COL6A3 & $\triangle$ & $\triangle$ & $\triangle$ & FNDC3A & & $\triangle$ & \\
\hline COMP & $\triangle$ & $\triangle$ & $\triangle$ & HMMR & & $\triangle$ & \\
\hline THBS2 & $\triangle$ & $\triangle$ & $\triangle$ & CAV1 & & & $\nabla$ \\
\hline FN1 & $\triangle$ & $\triangle$ & $\triangle$ & ACTN1 & & & $\nabla$ \\
\hline LAMB3 & $\nabla$ & $\nabla$ & $\nabla$ & ARHGAP5 & & & $\nabla$ \\
\hline LAMC2 & $\nabla$ & $\nabla$ & $\nabla$ & DOCK1 & & & $\triangle$ \\
\hline TNR & $\nabla$ & $\nabla$ & $\nabla$ & EGFR & & & $\nabla$ \\
\hline ITGB4 & $\nabla$ & $\nabla$ & $\nabla$ & JUN & & & $\nabla$ \\
\hline ITGA2 & & $\nabla$ & $\nabla$ & MET & & & $\nabla$ \\
\hline ITGA3 & & $\nabla$ & $\nabla$ & MYL9 & & & $\nabla$ \\
\hline ITGB8 & & $\nabla$ & $\nabla$ & MYLK & & & $\nabla$ \\
\hline COL17A1 & $\nabla$ & & & PARVB & & & $\triangle$ \\
\hline DSC3 & $\nabla$ & & & PDGFB & & & $\triangle$ \\
\hline DSG3 & $\nabla$ & & & PDGFRA & & & $\nabla$ \\
\hline DSG4 & $\nabla$ & & & PIK3CB & & & $\triangle$ \\
\hline KRT14 & $\nabla$ & & & VEGFA & & & $\triangle$ \\
\hline KRT15 & $\nabla$ & & & & & & \\
\hline
\end{tabular}

$\triangle$ corresponds to significantly overexpressed genes and $\nabla$ to significantly underexpressed genes. Note that $P a t h 1$ represents the Cell Junctions pathway, Path2 is the ECM-receptor interactions pathway, and Path3 is the Focal Adhesion pathway. It is noteworthy that there are several genes that are involved in more than 1 pathway, allowing crosstalk between pathways. 
in human metastatic breast cancer cells (Thompson et al., 1994). Other collagens, such as types III, V, and VII, also are altered with regard to expression and deposition in breast cancer (Barsky et al., 1982; Fukuda et al., 2000; Lagace et al., 1985; Wetzels et al., 1991), triggering signals that lead to the loss of structure and function in breast.

There also are several indications that the focal adhesion pathway is related to the progression of breast cancer. For instance, Lin et al. (2000) reported a direct effect of progesterone in inducing the spread and adhesion of breast cancer cells, with the conclusion that progesterone-induced cell spreading and focal adhesion may have significant implications in breast tumor metastasis. In addition, there is crosstalk between the ECM-receptor pathway and the focal adhesion pathway, in which several proteins bind to form ECMs that bind to their receptors, triggering signaling cascades within the focal adhesion pathway and leading to cell motility, cell proliferation, and cell survival (Fig. 2, 3).

Table 2 shows overexpressed and underexpressed genes in Cell Junctions, the ECM-receptor interaction pathway, and the Focal Adhesion pathway, including THBS2, PDGF, COL1A1, COLA2, COL3A1, COL5A1, and COL5A2. There are several indications that these genes are associated with cancer. For instance, THBS2 has been shown to function as a potent inhibitor of tumor growth and angiogenesis (Potikyan et al., 2007;
Hawighorst et al., 2001). PDGF is known to activate the RAS/PIK3/AKT1/IKK/NFKB1 pathway, in which NFKB1 induces putative antiapoptotic genes (Romashkova et al., 1999). Collagen type I (COL1A1, COL1A2), type III (COL3A1), and type $V$ (COL5A1, COL5A2) are implicated in playing roles in the progression of metastatic breast cancer (Barsky et al., 1982; Fukuda et al., 2000; Lagace et al., 1985; Thompson et al., 1994; Wetzels et al., 1991).

Based on the selected perturbed pathways, we combined selected metabolic pathways with protein-protein interaction information by constructing a subnetwork of protein-protein interactions (e.g., Fig. 4). To contruct a subnetwork of protein-protein interactions for each pathway, information on protein-protein interactions was extracted from the Human Protein Reference Database (HPRD) (Peri et al., 2004). Fig. 4 shows that protein complexes can be identified based on the definitions in individual metabolic pathways, in which the protein-protein interactions can be categorized into intra- or inter-pathway interactions. It also is possible to identify significantly perturbed proteins within the protein complexes for a more detailed analysis of the pathways.

Based on perturbation score, we present 36 significantly perturbed pathways, instead of collecting a large amount of significantly dysregulated individual genes. The selected pathways are then considered to be dysregulated functional modules that putatively con-
(A)

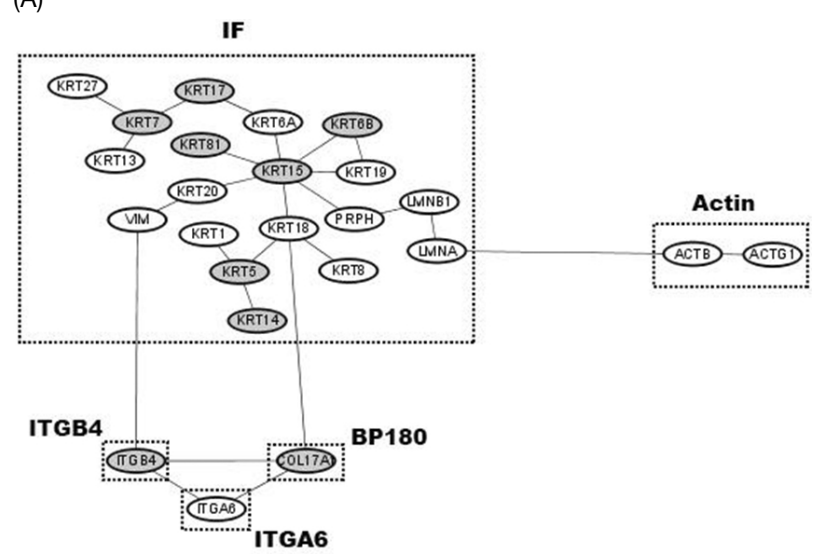

(B)

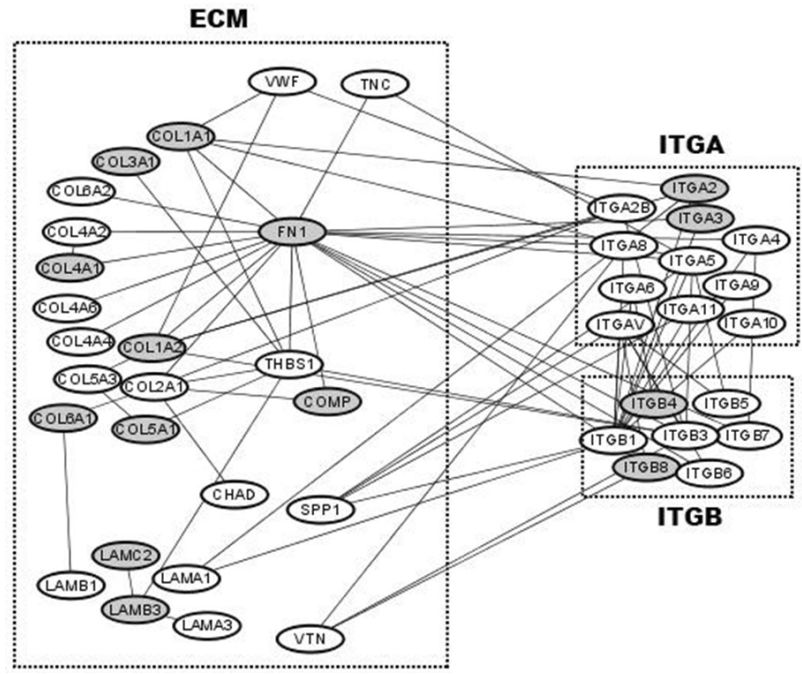

Fig. 4. (A) Subnetwork of protein-protein interactions in the Cell Junctions pathway. The rectangular boxes with dashed lines represent the protein complexes of IF, Actin, ITGB4, ITGA6, and BP180, respectively (see Fig. 1). (B) Subnetwork of protein-protein interactions in both the ECM-receptor Interaction and Focal Adhesion pathways. The rectangular boxes with dashed lines represent the protein complexes of ECM, ITGA, and ITGB, respectively (see Fig. 3). Note that 3 protein complexes in (B) can be subdivided into smaller protein complexes based on the definition of the ECM-receptor pathway (Fig. 2). Note also that grey-colored nodes represent significantly perturbed genes $(p<0.01)$ in breast cancer tissues. 
tribute to the progression of disease. The result of this study suggests that the strategy of microarray analysis, using the score of perturbation, selects several interesting perturbed pathways that are implicated in the progression of breast cancer. It also was found that these selected pathways include several known breast cancer-related genes. Therefore, based on the selected pathways, this study sets the stage for further investigation of the basic mechanisms that serve as a basis for discriminating different breast cancer types to find new therapeutic drug targets.

\section{Acknowledgments}

This research was supported by Sookmyung Women's University Research Grants 1-0703-0148.

\section{References}

Barsky, S.H., Rao, C.N., Grotendorst, G.R., and Liotta, L.A. (1982). Increased content of Type V Collagen in desmoplasia of human breast carcinoma. Am. J. Pathol. 108, 276-283.

Beer, D.G., Kardia, S.L., Huang, C.C., et al. (2002). Gene-expression profiles predict survival of patients with lung adenocarcinoma. Nat. Med. 8, 816-824.

Behmoaram, E., Bijian, K., Jie, S., Xu, Y., Darnel, A., Bismar, T.A., and Alaoui-Jamali, M.A. (2008). Focal adhesion kinase-related proline-rich tyrosine kinase 2 and focal adhesion kinase are co-overexpressed in early-stage and invasive ErbB-2-positive breast cancer and cooperate for breast cancer cell tumorigenesis and invasiveness. American Journal of Pathology 173, 1540-1550.

Chen, J., and Yuan, B. (2006). Detecting functional modules in the yeast protein-protein interaction network. Bioinformatics 22, 2283-2290.

Chuang, H.Y., Lee, E., Liu, Y.T., Lee, D., and Ideker, T. (2007). Network-based classification of breast cancer metastasis. Molecular Systems Biology 3, 140.

Dhanasekaran, S.M., Barrette, T.R., Ghosh, D., et al. (2001). Delineation of prognostic biomarkers in prostate cancer. Nature 412, 822-826.

Fata, J.E., Werb, Z., and Bissell, M.J. (2004). Regulation of mammary gland branching morphogenesis by the extracellular matrix and its remodeling enzymes. Breast Cancer Res. 6, 1-11.

Fukuda, Y., Ishizaki, M., Okada, Y., Seiki, M., and Yamanaka, N. (2000). Matrix metalloproteinases and tissue inhibitor of metalloproteinase-2 in fetal rabbit lung. Am. J. Physiol. Lung Cell Mol. Physiol. 279, 555-561.

Glinsky, G.V., Glinskii, A.B., Stephenson, A.J., Hoffman, R.M., and Gerald, W.L. (2004). Gene expression profiling predicts clinical outcome of prostate cancer. J. Clin. Invest. 113, 913-923.

Grosu, P., Townsend, J.P., Hartl, D.L., and Cavalieri, D. (2008). Pathway processor: a tool for integrating wholegenome expression results into metabolic networks.
Genome Research 12, 1121-1126.

Hawighorst, T., Velasco, P., Streit, M., Hong, Y.K., Kyriakides, T.R., Brown, L.R., Bornstein, P., and Detmar, M. (2001). Thrombospondin-2 plays a protective role in multistep carcinogenesis: a novel host anti-tumor defense mechanism. The EMBO Journal 20, 2631-2640.

Hwang, S., Son, S.W., Kim, S.C., Kim, Y.J., Jeong, H., and Lee, D. (2008). A protein interaction network associated with asthma. Journal of Theoretical Biology 252, 722-731.

Lagace, R., Grimaud, J.A., Schurch, W., and Seemayer, T.A. (1985). Myofibroblastic stromal reaction in carcinoma of the breast: variations of collagenous matrix and structural glycoproteins. Virchows Arch. A. Pathol. Anat. Histopathol. 408, 49-59.

Lin, V.C., Ng, E.H., Aw, S.E., Tan, M.G., Ng, E.H., and Bay, B.H. (2000). Progesterone Induces Focal Adhesion in Breast Cancer Cells MDA-MB-231 Transfected with progesterone receptor complementary DNA. Molecular Endocrinology 14, 348-358.

Lochter, A., and Bissell, M.J. (1995). Involvement of extracellular matrix constituents in breast cancer. Semin. Cancer Biol. 6, 165-173.

Peri, S., Navarro, J.D., Kristiansen, T.Z., Amanchy, R., Surendranath, V., Muthusamy, B., Gandhi, T.K., Chandrika, K.N., Deshpande, N., Suresh, S., Rashmi, B.P., Shanker, K., Padma, N., Niranjan, V., Harsha, H.C., Talreja, N., Vrushabendra, B.M., Ramya, M.A., Yatish, A.J., Joy, M., Shivashankar, H.N., Kavitha, M.P., Menezes, M., Choudhury, D.R., Ghosh, N., Saravana, R., Chandran, S., Mohan, S., Jonnalagadda, C.K., Prasad, C.K., Kumar-Sinha, C., Deshpande, K.S., and Pandey, A. (2004). Human protein reference database as a discovery resource for proteomics. Nucleic Acids Res. 32, D497D501.

Petersen, O.W., Lind, N.H., Gudjonsson, T., Villadsen, R., Ronnov-Jessen, L., and Bissell, M.J. (2001). The plasticity of human breast carcinoma cells is more than epithelial to mesenchymal conversion. Breast Cancer Res. 3, 213-217.

Potikyan, G., Savene, O.V., Gaulden, J.M., France, K.A., Zhou, Z., Kleinerman, E.S., Lessnick, S.L., and Denny, C.T. (2007). EWS/FLI1 regulates tumor angiogenesis in Ewing's sarcoma via suppression of thrombospondins. Cancer Research 67, 6675-6684.

Romashkova, J.A., and Makarov, S.S. (1999). NF-kappa-B is a target of AKT in anti-apoptotic PDGF signalling. Nature 401, 86-90.

Ryan, K.M., Ernst, M.K., Rice, N.R., and Vousden, K.H. (2000). Role of NF-kappa-B in p53-mediated programmed cell death. Nature 404, 892-897.

Setlur, S.R., Royce, T.E., Sboner, A., Mosquera, J.M., Demichelis, F., Hofer, M.D., Mertz, K.D., Gerstein, M., and Rubin, M.A. (2007). Integrative microarray analysis of pathways dysregulated in metastatic prostate cancer. Cancer Res. 67, 10296-10303.

Thompson, E.W., Yu, M., Bueno, J., Jin, L., Maiti, S.N., Palao-Marco, F.L., Pulyaeva, H., Tamborlane, J.W., Tirgari, R., Wapnir, I., et al. (1994). Collagen induced MMP-2 activation in human breast cancer. Breast Cancer 
Res. Treat, 31, 357-370.

Turashvili, G., Bouchal, J., Baumforth, K., Wei, W., et al. (2007). Novel markers for differentiation of lobular and ductal invasive breast carcinomas by laser microdissection and microarray analysis. BMC Cancer 7, 55. van de Vijver, M.J., He, Y.D., van't Veer, L.J., Dai, H., Hart, A.A., Voskuil, D.W., Schreiber, G.J., Peterse, J.L., Roberts, C., Marton, M.J., Parrish, M., Atsma, D., Witteveen, A., Glas, A., Delahaye, L., van der Velde, T., Bartelink, H., Rodenhuis, S., Rutgers, E.T., Friend, S.H., and Bernards, R. (2002). A gene-expression signature as a predictor of survival in breast cancer. N. Engl. J. Med. 347, 1999-2009.

van't Veer, L.J., Dai, H., van de Vijver, M.J., et al. (2002). Gene expression profiling predicts clinical outcome of breast cancer. Nature 415, 530-536. van't Veer, L.J., Dai, H., van de Vijver, M.J., He, Y.D., Hart, A.A., Bernards, R., and Friend, S.H. (2002). Expression profiling predicts outcome in breast cancer. Breast Cancer Res. 5, 57-58.

Wang, W., Wyckoff, J.B., Frohlich, V.C., Oleynikov, Y., Huttelmaier, S., Zavadil, J., Cermak, L., Bottinger, E.P., Singer, R.H., White, J.G., Segall, J.E., and Condeelis, J.S. (2002). Single cell behavior in metastatic primary mammary tumors correlated with gene expression patterns revealed by molecular profiling. Cancer Res. 62, 6278-6288.

Wetzels, R.H., Robben, H.C., Leigh, I.M., Schaafsma, H.E., Vooijs, G.P., and Ramaekers, F.C. (1991). Distribution patterns of type VII collagen in normal and malignant human tissues. Am. J. Pathol. 139, 451-459. 
Supplementary Table S1. The list of all pathways from KEGG database, which are sorted according to the scores of perturbation. Note that $N 1$ represents the total number of genes in each pathway, $N 2$ is the number of overexpressed genes $(p<0.01)$ in each pathway, $N 3$ is the number of underexpressed genes $(p<0.01)$ in each pathway, $N 4$ is the total number of significantly perturbed genes in each pathway (i.e., $N 4=N 2+N 3$ ), and $N 5$ is the score of perturbation i.e., p-values by the cumulative hypergeometric distribution

\begin{tabular}{|c|c|c|c|c|c|c|c|c|c|}
\hline \multirow{2}{*}{ KEGG Pathway Description } & \multirow{2}{*}{$\begin{array}{c}\text { \# of } \\
\text { genes in } \\
\text { pathway }\end{array}$} & \multirow{2}{*}{$\begin{array}{c}\text { \# of } \\
\text { genes } \\
\text { linked to - } \\
\text { GPL570 } \\
\text { Probes }\end{array}$} & \multicolumn{2}{|c|}{$\begin{array}{c}\quad \mathrm{p}<0.05 \\
\# \text { of Over } \\
\text { Expressed Genes }\end{array}$} & \multicolumn{2}{|c|}{$\begin{array}{c}\mathrm{p}<0.01 \\
\text { \# of Over } \\
\text { Expressed Genes }\end{array}$} & \multirow{2}{*}{ P1 } & \multirow{2}{*}{ P2 } & \multirow{2}{*}{ P3 } \\
\hline & & & $\begin{array}{l}\text { Lobular } \\
\text { Carci- } \\
\text { noma }\end{array}$ & $\begin{array}{l}\text { Ductal } \\
\text { Carci- } \\
\text { noma }\end{array}$ & $\begin{array}{c}\text { Lobular } \\
\text { Carci- } \\
\text { noma }\end{array}$ & $\begin{array}{l}\text { Ductal } \\
\text { Carci- } \\
\text { noma }\end{array}$ & & & \\
\hline Systemic lupus erythematosus & 134 & 122 & 6 & 55 & 1 & 34 & 0.8 & 27.9 & 14.3 \\
\hline Keratan sulfate biosynthesis & 16 & 16 & 1 & 4 & 1 & 3 & 6.3 & 18.8 & 12.5 \\
\hline ECM-receptor interaction & 88 & 87 & 18 & 25 & 8 & 11 & 9.2 & 12.6 & 10.9 \\
\hline Chondroitin sulfate biosynthesis & 22 & 22 & 1 & 5 & 1 & 2 & 4.5 & 9.1 & 6.8 \\
\hline Cell junctions & 138 & 134 & 15 & 26 & 8 & 10 & 6.0 & 7.5 & 6.7 \\
\hline Maturity onset diabetes of the young & 25 & 23 & 2 & 7 & 1 & 2 & 4.3 & 8.7 & 6.5 \\
\hline alpha-Linolenic acid metabolism & 17 & 17 & 2 & 3 & 1 & 1 & 5.9 & 5.9 & 5.9 \\
\hline Linoleic acid metabolism & 29 & 29 & 1 & 4 & 1 & 2 & 3.4 & 6.9 & 5.2 \\
\hline Focal adhesion & 200 & 198 & 28 & 29 & 10 & 10 & 5.1 & 5.1 & 5.1 \\
\hline Glycosphingolipid biosynthesis - lactoseries & 10 & 10 & 0 & 3 & 0 & 1 & 0.0 & 10.0 & 5.0 \\
\hline Glycosphingolipid biosynthesis - neo-lactoseries & 21 & 21 & 2 & 4 & 0 & 2 & 0.0 & 9.5 & 4.8 \\
\hline Reductive carboxylate cycle (CO2 fixation) & 11 & 11 & 1 & 1 & 0 & 1 & 0.0 & 9.1 & 4.5 \\
\hline Ether lipid metabolism & 33 & 33 & 4 & 4 & 2 & 1 & 6.1 & 3.0 & 4.5 \\
\hline Nitrogen metabolism & 24 & 24 & 2 & 1 & 1 & 1 & 4.2 & 4.2 & 4.2 \\
\hline Valine, leucine and isoleucine biosynthesis & 12 & 12 & 3 & 2 & 0 & 1 & 0.0 & 8.3 & 4.2 \\
\hline Glycan structures - biosynthesis 2 & 63 & 63 & 4 & 11 & 1 & 4 & 1.6 & 6.3 & 4.0 \\
\hline Prion disease & 14 & 13 & 1 & 2 & 0 & 1 & 0.0 & 7.7 & 3.8 \\
\hline Protein export & 15 & 14 & 1 & 2 & 1 & 0 & 7.1 & 0.0 & 3.6 \\
\hline Graft-versus-host disease & 42 & 42 & 3 & 8 & 0 & 3 & 0.0 & 7.1 & 3.6 \\
\hline Glycosphingolipid biosynthesis - globoseries & 14 & 14 & 0 & 2 & 0 & 1 & 0.0 & 7.1 & 3.6 \\
\hline Sulfur metabolism & 14 & 14 & 4 & 2 & 0 & 1 & 0.0 & 7.1 & 3.6 \\
\hline Bladder cancer & 42 & 42 & 8 & 9 & 2 & 1 & 4.8 & 2.4 & 3.6 \\
\hline GnRH signaling pathway & 100 & 100 & 10 & 12 & 5 & 2 & 5.0 & 2.0 & 3.5 \\
\hline ABC transporters - General & 44 & 43 & 3 & 4 & 2 & 1 & 4.7 & 2.3 & 3.5 \\
\hline Glycerophospholipid metabolism & 72 & 72 & 8 & 5 & 2 & 3 & 2.8 & 4.2 & 3.5 \\
\hline VEGF signaling pathway & 73 & 73 & 6 & 9 & 3 & 2 & 4.1 & 2.7 & 3.4 \\
\hline Cell adhesion molecules (CAMs) & 133 & 132 & 7 & 24 & 1 & 8 & 0.8 & 6.1 & 3.4 \\
\hline Type I diabetes mellitus & 44 & 44 & 4 & 8 & 0 & 3 & 0.0 & 6.8 & 3.4 \\
\hline Toll-like receptor signaling pathway & 107 & 104 & 11 & 17 & 3 & 4 & 2.9 & 3.8 & 3.4 \\
\hline Pyrimidine metabolism & 91 & 90 & 6 & 18 & 1 & 5 & 1.1 & 5.6 & 3.3 \\
\hline Riboflavin metabolism & 16 & 16 & 1 & 1 & 1 & 0 & 6.3 & 0.0 & 3.1 \\
\hline One carbon pool by folate & 16 & 16 & 2 & 4 & 0 & 1 & 0.0 & 6.3 & 3.1 \\
\hline Cell cycle & 119 & 115 & 14 & 22 & 0 & 7 & 0.0 & 6.1 & 3.0 \\
\hline Propanoate metabolism & 34 & 33 & 2 & 3 & 1 & 1 & 3.0 & 3.0 & 3.0 \\
\hline Renin-angiotensin system & 17 & 17 & 2 & 2 & 1 & 0 & 5.9 & 0.0 & 2.9 \\
\hline Cysteine metabolism & 17 & 17 & 2 & 1 & 0 & 1 & 0.0 & 5.9 & 2.9 \\
\hline Glycan structures - biosynthesis 1 & 123 & 121 & 8 & 21 & 2 & 5 & 1.7 & 4.1 & 2.9 \\
\hline Basal transcription factors & 37 & 35 & 1 & 5 & 0 & 2 & 0.0 & 5.7 & 2.9 \\
\hline Autoimmune thyroid disease & 53 & 53 & 5 & 10 & 0 & 3 & 0.0 & 5.7 & 2.8 \\
\hline Arachidonic acid metabolism & 56 & 55 & 1 & 4 & 1 & 2 & 1.8 & 3.6 & 2.7 \\
\hline Nicotinate and nicotinamide metabolism & 37 & 37 & 1 & 4 & 0 & 2 & 0.0 & 5.4 & 2.7 \\
\hline $\mathrm{T}$ cell receptor signaling pathway & 93 & 93 & 6 & 17 & 1 & 4 & 1.1 & 4.3 & 2.7 \\
\hline Ribosome & 91 & 75 & 0 & 15 & 0 & 4 & 0.0 & 5.3 & 2.7 \\
\hline Fructose and mannose metabolism & 38 & 38 & 2 & 3 & 1 & 1 & 2.6 & 2.6 & 2.6 \\
\hline Allograft rejection & 38 & 38 & 4 & 6 & 0 & 2 & 0.0 & 5.3 & 2.6 \\
\hline Fc epsilon RI signaling pathway & 77 & 77 & 7 & 7 & 3 & 1 & 3.9 & 1.3 & 2.6 \\
\hline
\end{tabular}


Supplementary Table S1. Continued

\begin{tabular}{|c|c|c|c|c|c|c|c|c|c|}
\hline \multirow{2}{*}{ KEGG Pathway Description } & \multirow{2}{*}{$\begin{array}{c}\text { \# of } \\
\text { genes in } \\
\text { pathway }\end{array}$} & \multirow{2}{*}{$\begin{array}{c}\text { \# of } \\
\text { genes } \\
\text { linked to } \\
\text { GPL570 } \\
\text { Probes }\end{array}$} & \multicolumn{2}{|c|}{$\begin{array}{c}\mathrm{p}<0.05 \\
\# \text { of Over } \\
\text { Expressed Genes }\end{array}$} & \multicolumn{2}{|c|}{$\begin{array}{c}\mathrm{p}<0.01 \\
\# \text { of Over } \\
\text { Expressed Genes }\end{array}$} & \multirow{2}{*}{ P1 } & \multirow{2}{*}{$\mathrm{P} 2$} & \multirow{2}{*}{ P3 } \\
\hline & & & $\begin{array}{l}\text { Lobular } \\
\text { Carci- } \\
\text { noma }\end{array}$ & $\begin{array}{l}\text { Ductal } \\
\text { Carci- } \\
\text { noma }\end{array}$ & $\begin{array}{l}\text { Lobular } \\
\text { Carci- } \\
\text { noma }\end{array}$ & $\begin{array}{l}\text { Ductal } \\
\text { Carci- } \\
\text { noma }\end{array}$ & & & \\
\hline Long-term depression & 78 & 78 & 4 & 10 & 2 & 2 & 2.6 & 2.6 & 2.6 \\
\hline Parkinson's disease & 20 & 20 & 0 & 5 & 0 & 1 & 0.0 & 5.0 & 2.5 \\
\hline Glycosphingolipid biosynthesis - ganglioseries & 21 & 20 & 1 & 4 & 0 & 1 & 0.0 & 5.0 & 2.5 \\
\hline Glycolysis / Gluconeogenesis & 62 & 61 & 3 & 9 & 0 & 3 & 0.0 & 4.9 & 2.5 \\
\hline Methionine metabolism & 21 & 21 & 1 & 3 & 0 & 1 & 0.0 & 4.8 & 2.4 \\
\hline Amyotrophic lateral sclerosis (ALS) & 21 & 21 & 0 & 2 & 0 & 1 & 0.0 & 4.8 & 2.4 \\
\hline Glioma & 65 & 65 & 8 & 9 & 2 & 1 & 3.1 & 1.5 & 2.3 \\
\hline Metabolism of xenobiotics by cytochrome P450 & 70 & 65 & 1 & 5 & 0 & 3 & 0.0 & 4.6 & 2.3 \\
\hline TGF-beta signaling pathway & 90 & 87 & 9 & 10 & 1 & 3 & 1.1 & 3.4 & 2.3 \\
\hline Valine, leucine and isoleucine degradation & 44 & 44 & 1 & 3 & 1 & 1 & 2.3 & 2.3 & 2.3 \\
\hline $\mathrm{N}$-Glycan biosynthesis & 45 & 44 & 2 & 2 & 1 & 1 & 2.3 & 2.3 & 2.3 \\
\hline Prostate cancer & 91 & 91 & 13 & 13 & 2 & 2 & 2.2 & 2.2 & 2.2 \\
\hline $\begin{array}{l}\text { Glycosylphosphatidylinositol(GPI)-anchor biosyn- } \\
\text { thesis }\end{array}$ & 23 & 23 & 1 & 1 & 1 & 0 & 4.3 & 0.0 & 2.2 \\
\hline $\begin{array}{l}\text { Epithelial cell signaling in Helicobacter pylori in- } \\
\text { fection }\end{array}$ & 69 & 69 & 7 & 9 & 2 & 1 & 2.9 & 1.4 & 2.2 \\
\hline Mismatch repair & 23 & 23 & 1 & 2 & 0 & 1 & 0.0 & 4.3 & 2.2 \\
\hline Melanoma & 71 & 71 & 8 & 13 & 2 & 1 & 2.8 & 1.4 & 2.1 \\
\hline Pantothenate and CoA biosynthesis & 24 & 24 & 0 & 3 & 0 & 1 & 0.0 & 4.2 & 2.1 \\
\hline B cell receptor signaling pathway & 73 & 73 & 4 & 16 & 1 & 2 & 1.4 & 2.7 & 2.1 \\
\hline mTOR signaling pathway & 51 & 50 & 6 & 6 & 1 & 1 & 2.0 & 2.0 & 2.0 \\
\hline Inositol phosphate metabolism & 51 & 51 & 7 & 5 & 0 & 2 & 0.0 & 3.9 & 2.0 \\
\hline Galactose metabolism & 26 & 26 & 2 & 3 & 0 & 1 & 0.0 & 3.8 & 1.9 \\
\hline Phenylalanine metabolism & 26 & 26 & 0 & 2 & 0 & 1 & 0.0 & 3.8 & 1.9 \\
\hline Non-small cell lung cancer & 54 & 54 & 7 & 8 & 1 & 1 & 1.9 & 1.9 & 1.9 \\
\hline Hedgehog signaling pathway & 57 & 55 & 2 & 9 & 0 & 2 & 0.0 & 3.6 & 1.8 \\
\hline Urea cycle and metabolism of amino groups & 28 & 28 & 1 & 1 & 1 & 0 & 3.6 & 0.0 & 1.8 \\
\hline Hematopoietic cell lineage & 87 & 86 & 6 & 16 & 0 & 3 & 0.0 & 3.5 & 1.7 \\
\hline Leukocyte transendothelial migration & 116 & 115 & 9 & 13 & 2 & 2 & 1.7 & 1.7 & 1.7 \\
\hline Thyroid cancer & 29 & 29 & 3 & 6 & 1 & 0 & 3.4 & 0.0 & 1.7 \\
\hline Small cell lung cancer & 87 & 87 & 10 & 16 & 0 & 3 & 0.0 & 3.4 & 1.7 \\
\hline Aminosugars metabolism & 29 & 29 & 2 & 2 & 0 & 1 & 0.0 & 3.4 & 1.7 \\
\hline Purine metabolism & 147 & 146 & 10 & 20 & 1 & 4 & 0.7 & 2.7 & 1.7 \\
\hline Wnt signaling pathway & 149 & 146 & 7 & 14 & 1 & 4 & 0.7 & 2.7 & 1.7 \\
\hline Antigen processing and presentation & 88 & 88 & 7 & 11 & 0 & 3 & 0.0 & 3.4 & 1.7 \\
\hline Vibrio cholerae infection & 59 & 59 & 4 & 10 & 1 & 1 & 1.7 & 1.7 & 1.7 \\
\hline Olfactory transduction & 383 & 118 & 3 & 13 & 0 & 4 & 0.0 & 3.4 & 1.7 \\
\hline MAPK signaling pathway & 269 & 268 & 15 & 37 & 4 & 5 & 1.5 & 1.9 & 1.7 \\
\hline Retinol metabolism & 65 & 60 & 4 & 4 & 1 & 1 & 1.7 & 1.7 & 1.7 \\
\hline Glutamate metabolism & 31 & 31 & 4 & 2 & 1 & 0 & 3.2 & 0.0 & 1.6 \\
\hline Gap junction & 96 & 94 & 5 & 13 & 2 & 1 & 2.1 & 1.1 & 1.6 \\
\hline Huntington's disease & 32 & 32 & 1 & 1 & 1 & 0 & 3.1 & 0.0 & 1.6 \\
\hline Axon guidance & 128 & 128 & 10 & 18 & 1 & 3 & 0.8 & 2.3 & 1.6 \\
\hline Bile acid biosynthesis & 33 & 33 & 1 & 2 & 0 & 1 & 0.0 & 3.0 & 1.5 \\
\hline Drug metabolism - cytochrome P450 & 72 & 67 & 1 & 6 & 0 & 2 & 0.0 & 3.0 & 1.5 \\
\hline p53 signaling pathway & 69 & 68 & 9 & 16 & 0 & 2 & 0.0 & 2.9 & 1.5 \\
\hline Renal cell carcinoma & 69 & 69 & 6 & 8 & 1 & 1 & 1.4 & 1.4 & 1.4 \\
\hline Natural killer cell mediated cytotoxicity & 141 & 138 & 10 & 18 & 1 & 3 & 0.7 & 2.2 & 1.4 \\
\hline Complement and coagulation cascades & 69 & 69 & 3 & 6 & 0 & 2 & 0.0 & 2.9 & 1.4 \\
\hline Long-term potentiation & 70 & 70 & 1 & 10 & 1 & 1 & 1.4 & 1.4 & 1.4 \\
\hline
\end{tabular}


Supplementary Table S1. Continued

\begin{tabular}{|c|c|c|c|c|c|c|c|c|c|}
\hline \multirow{2}{*}{ KEGG Pathway Description } & \multirow{2}{*}{$\begin{array}{c}\text { \# of } \\
\text { genes in } \\
\text { pathway }\end{array}$} & \multirow{2}{*}{$\begin{array}{c}\text { \# of } \\
\text { genes } \\
\text { linked to } \\
\text { GPL570 } \\
\text { Probes }\end{array}$} & \multicolumn{2}{|c|}{$\begin{array}{c}\mathrm{p}<0.05 \\
\# \text { of Over } \\
\text { Expressed Genes }\end{array}$} & \multicolumn{2}{|c|}{$\begin{array}{c}\mathrm{p}<0.01 \\
\# \text { of Over } \\
\text { Expressed Genes }\end{array}$} & \multirow{2}{*}{ P1 } & \multirow{2}{*}{ P2 } & \multirow{2}{*}{ P3 } \\
\hline & & & $\begin{array}{l}\text { Lobular } \\
\text { Carci- } \\
\text { noma }\end{array}$ & $\begin{array}{l}\text { Ductal } \\
\text { Carci- } \\
\text { noma }\end{array}$ & $\begin{array}{l}\text { Lobular } \\
\text { Carci- } \\
\text { noma }\end{array}$ & $\begin{array}{l}\text { Ductal } \\
\text { Carci- } \\
\text { noma }\end{array}$ & & & \\
\hline Base excision repair & 35 & 35 & 1 & 7 & 0 & 1 & 0.0 & 2.9 & 1.4 \\
\hline Primary immunodeficiency & 35 & 35 & 2 & 6 & 0 & 1 & 0.0 & 2.9 & 1.4 \\
\hline Arginine and proline metabolism & 35 & 35 & 3 & 2 & 0 & 1 & 0.0 & 2.9 & 1.4 \\
\hline Regulation of actin cytoskeleton & 219 & 216 & 19 & 28 & 3 & 3 & 1.4 & 1.4 & 1.4 \\
\hline DNA replication & 36 & 36 & 2 & 5 & 0 & 1 & 0.0 & 2.8 & 1.4 \\
\hline Pancreatic cancer & 73 & 73 & 8 & 12 & 2 & 0 & 2.7 & 0.0 & 1.4 \\
\hline Folate biosynthesis & 39 & 38 & 3 & 4 & 1 & 0 & 2.6 & 0.0 & 1.3 \\
\hline Neurodegenerative Diseases & 39 & 39 & 0 & 3 & 0 & 1 & 0.0 & 2.6 & 1.3 \\
\hline Phosphatidylinositol signaling system & 80 & 80 & 7 & 7 & 0 & 2 & 0.0 & 2.5 & 1.3 \\
\hline Pyruvate metabolism & 42 & 42 & 1 & 4 & 0 & 1 & 0.0 & 2.4 & 1.2 \\
\hline Colorectal cancer & 85 & 85 & 9 & 7 & 2 & 0 & 2.4 & 0.0 & 1.2 \\
\hline Type II diabetes mellitus & 44 & 43 & 2 & 8 & 0 & 1 & 0.0 & 2.3 & 1.2 \\
\hline Nucleotide excision repair & 43 & 43 & 1 & 5 & 0 & 1 & 0.0 & 2.3 & 1.2 \\
\hline ErbB signaling pathway & 87 & 87 & 5 & 7 & 2 & 0 & 2.3 & 0.0 & 1.1 \\
\hline Apoptosis & 89 & 88 & 6 & 12 & 0 & 2 & 0.0 & 2.3 & 1.1 \\
\hline Notch signaling pathway & 46 & 46 & 3 & 3 & 1 & 0 & 2.2 & 0.0 & 1.1 \\
\hline Taste transduction & 53 & 46 & 2 & 8 & 0 & 1 & 0.0 & 2.2 & 1.1 \\
\hline Histidine metabolism & 50 & 50 & 0 & 4 & 0 & 1 & 0.0 & 2.0 & 1.0 \\
\hline Endometrial cancer & 52 & 52 & 6 & 5 & 1 & 0 & 1.9 & 0.0 & 1.0 \\
\hline Basal cell carcinoma & 55 & 54 & 1 & 5 & 0 & 1 & 0.0 & 1.9 & 0.9 \\
\hline Acute myeloid leukemia & 58 & 58 & 6 & 8 & 1 & 0 & 1.7 & 0.0 & 0.9 \\
\hline Tyrosine metabolism & 58 & 58 & 3 & 3 & 0 & 1 & 0.0 & 1.7 & 0.9 \\
\hline Neuroactive ligand-receptor interaction & 303 & 302 & 9 & 39 & 1 & 4 & 0.3 & 1.3 & 0.8 \\
\hline Oxidative phosphorylation & 129 & 125 & 8 & 23 & 1 & 1 & 0.8 & 0.8 & 0.8 \\
\hline Tight junction & 135 & 134 & 5 & 14 & 1 & 1 & 0.7 & 0.7 & 0.7 \\
\hline PPAR signaling pathway & 69 & 68 & 7 & 4 & 0 & 1 & 0.0 & 1.5 & 0.7 \\
\hline Cytokine-cytokine receptor interaction & 279 & 273 & 17 & 35 & 1 & 3 & 0.4 & 1.1 & 0.7 \\
\hline Insulin signaling pathway & 139 & 138 & 6 & 12 & 2 & 0 & 1.4 & 0.0 & 0.7 \\
\hline Adherens junction & 75 & 75 & 2 & 6 & 0 & 1 & 0.0 & 1.3 & 0.7 \\
\hline Chronic myeloid leukemia & 76 & 76 & 7 & 12 & 1 & 0 & 1.3 & 0.0 & 0.7 \\
\hline Jak-STAT signaling pathway & 155 & 155 & 15 & 22 & 1 & 1 & 0.6 & 0.6 & 0.6 \\
\hline Calcium signaling pathway & 176 & 176 & 9 & 23 & 1 & 1 & 0.6 & 0.6 & 0.6 \\
\hline Melanogenesis & 102 & 101 & 5 & 9 & 1 & 0 & 1.0 & 0.0 & 0.5 \\
\hline Ubiquitin mediated proteolysis & 136 & 133 & 8 & 24 & 0 & 1 & 0.0 & 0.8 & 0.4 \\
\hline Adipocytokine signaling pathway & 72 & 72 & 5 & 10 & 0 & 0 & 0.0 & 0.0 & 0.0 \\
\hline Starch and sucrose metabolism & 79 & 75 & 3 & 7 & 0 & 0 & 0.0 & 0.0 & 0.0 \\
\hline Pathogenic Escherichia coli infection - EHEC & 51 & 49 & 0 & 6 & 0 & 0 & 0.0 & 0.0 & 0.0 \\
\hline Pathogenic Escherichia coli infection - EPEC & 51 & 49 & 0 & 6 & 0 & 0 & 0.0 & 0.0 & 0.0 \\
\hline Biosynthesis of steroids & 24 & 24 & 0 & 5 & 0 & 0 & 0.0 & 0.0 & 0.0 \\
\hline O-Glycan biosynthesis & 31 & 31 & 3 & 5 & 0 & 0 & 0.0 & 0.0 & 0.0 \\
\hline Heparan sulfate biosynthesis & 20 & 19 & 2 & 5 & 0 & 0 & 0.0 & 0.0 & 0.0 \\
\hline Sphingolipid metabolism & 39 & 38 & 3 & 5 & 0 & 0 & 0.0 & 0.0 & 0.0 \\
\hline Terpenoid biosynthesis & 6 & 6 & 0 & 5 & 0 & 0 & 0.0 & 0.0 & 0.0 \\
\hline Glycine, serine and threonine metabolism & 42 & 42 & 1 & 4 & 0 & 0 & 0.0 & 0.0 & 0.0 \\
\hline Tryptophan metabolism & 58 & 58 & 0 & 4 & 0 & 0 & 0.0 & 0.0 & 0.0 \\
\hline Fatty acid metabolism & 46 & 46 & 3 & 3 & 0 & 0 & 0.0 & 0.0 & 0.0 \\
\hline Alanine and aspartate metabolism & 33 & 33 & 1 & 3 & 0 & 0 & 0.0 & 0.0 & 0.0 \\
\hline Lysine degradation & 52 & 52 & 1 & 3 & 0 & 0 & 0.0 & 0.0 & 0.0 \\
\hline Glutathione metabolism & 50 & 47 & 1 & 3 & 0 & 0 & 0.0 & 0.0 & 0.0 \\
\hline Glycosaminoglycan degradation & 17 & 17 & 0 & 3 & 0 & 0 & 0.0 & 0.0 & 0.0 \\
\hline
\end{tabular}


Supplementary Table S1. Continued

\begin{tabular}{|c|c|c|c|c|c|c|c|c|c|}
\hline \multirow{2}{*}{ KEGG Pathway Description } & \multirow{2}{*}{$\begin{array}{c}\text { \# of } \\
\text { genes in } \\
\text { pathway }\end{array}$} & \multirow{2}{*}{$\begin{array}{l}\text { \# of } \\
\text { genes } \\
\text { linked to - } \\
\text { GPL570 } \\
\text { Probes }\end{array}$} & \multicolumn{2}{|c|}{$\begin{array}{c}\quad \mathrm{p}<0.05 \\
\# \text { of Over } \\
\text { Expressed Genes }\end{array}$} & \multicolumn{2}{|c|}{$\begin{array}{c}\mathrm{p}<0.01 \\
\# \text { of Over } \\
\text { Expressed Genes }\end{array}$} & \multirow{2}{*}{$\mathrm{P} 1$} & \multirow{2}{*}{ P2 } & \multirow{2}{*}{ P3 } \\
\hline & & & $\begin{array}{l}\text { Lobular } \\
\text { Carci- } \\
\text { noma }\end{array}$ & $\begin{array}{l}\text { Ductal } \\
\text { Carci- } \\
\text { noma }\end{array}$ & $\begin{array}{l}\text { Lobular } \\
\text { Carci- } \\
\text { noma }\end{array}$ & $\begin{array}{l}\text { Ductal } \\
\text { Carci- } \\
\text { noma }\end{array}$ & & & \\
\hline Benzoate degradation via CoA ligation & 23 & 23 & 0 & 3 & 0 & 0 & 0.0 & 0.0 & 0.0 \\
\hline Butanoate metabolism & 36 & 36 & 0 & 3 & 0 & 0 & 0.0 & 0.0 & 0.0 \\
\hline Carbon fixation & 24 & 24 & 0 & 3 & 0 & 0 & 0.0 & 0.0 & 0.0 \\
\hline Atrazine degradation & 9 & 9 & 0 & 3 & 0 & 0 & 0.0 & 0.0 & 0.0 \\
\hline Porphyrin and chlorophyll metabolism & 41 & 37 & 0 & 3 & 0 & 0 & 0.0 & 0.0 & 0.0 \\
\hline Aminoacyl-tRNA biosynthesis & 39 & 39 & 4 & 3 & 0 & 0 & 0.0 & 0.0 & 0.0 \\
\hline Glycan structures - degradation & 30 & 30 & 0 & 3 & 0 & 0 & 0.0 & 0.0 & 0.0 \\
\hline Biosynthesis of unsaturated fatty acids & 23 & 23 & 2 & 3 & 0 & 0 & 0.0 & 0.0 & 0.0 \\
\hline Homologous recombination & 28 & 28 & 0 & 3 & 0 & 0 & 0.0 & 0.0 & 0.0 \\
\hline Regulation of autophagy & 34 & 33 & 2 & 3 & 0 & 0 & 0.0 & 0.0 & 0.0 \\
\hline Pentose phosphate pathway & 26 & 26 & 0 & 2 & 0 & 0 & 0.0 & 0.0 & 0.0 \\
\hline Androgen and estrogen metabolism & 55 & 52 & 1 & 2 & 0 & 0 & 0.0 & 0.0 & 0.0 \\
\hline gamma-Hexachlorocyclohexane degradation & 18 & 18 & 0 & 2 & 0 & 0 & 0.0 & 0.0 & 0.0 \\
\hline Glycerolipid metabolism & 51 & 50 & 4 & 2 & 0 & 0 & 0.0 & 0.0 & 0.0 \\
\hline Alkaloid biosynthesis ॥ & 20 & 20 & 0 & 2 & 0 & 0 & 0.0 & 0.0 & 0.0 \\
\hline Drug metabolism - other enzymes & 52 & 49 & 0 & 2 & 0 & 0 & 0.0 & 0.0 & 0.0 \\
\hline RNA polymerase & 25 & 25 & 2 & 2 & 0 & 0 & 0.0 & 0.0 & 0.0 \\
\hline Proteasome & 35 & 35 & 1 & 2 & 0 & 0 & 0.0 & 0.0 & 0.0 \\
\hline Non-homologous end-joining & 14 & 13 & 0 & 2 & 0 & 0 & 0.0 & 0.0 & 0.0 \\
\hline Alzheimer's disease & 28 & 28 & 1 & 2 & 0 & 0 & 0.0 & 0.0 & 0.0 \\
\hline Dentatorubropallidoluysian atrophy (DRPLA) & 15 & 15 & 1 & 2 & 0 & 0 & 0.0 & 0.0 & 0.0 \\
\hline Citrate cycle (TCA cycle) & 28 & 27 & 1 & 1 & 0 & 0 & 0.0 & 0.0 & 0.0 \\
\hline Synthesis and degradation of ketone bodies & 9 & 9 & 0 & 1 & 0 & 0 & 0.0 & 0.0 & 0.0 \\
\hline C21-Steroid hormone metabolism & 11 & 11 & 0 & 1 & 0 & 0 & 0.0 & 0.0 & 0.0 \\
\hline Lysine biosynthesis & 5 & 5 & 0 & 1 & 0 & 0 & 0.0 & 0.0 & 0.0 \\
\hline beta-Alanine metabolism & 24 & 24 & 0 & 1 & 0 & 0 & 0.0 & 0.0 & 0.0 \\
\hline Selenoamino acid metabolism & 32 & 32 & 1 & 1 & 0 & 0 & 0.0 & 0.0 & 0.0 \\
\hline 1- and 2-Methylnaphthalene degradation & 19 & 19 & 1 & 1 & 0 & 0 & 0.0 & 0.0 & 0.0 \\
\hline Glyoxylate and dicarboxylate metabolism & 15 & 15 & 2 & 1 & 0 & 0 & 0.0 & 0.0 & 0.0 \\
\hline 3-Chloroacrylic acid degradation & 14 & 14 & 1 & 1 & 0 & 0 & 0.0 & 0.0 & 0.0 \\
\hline Limonene and pinene degradation & 24 & 24 & 0 & 1 & 0 & 0 & 0.0 & 0.0 & 0.0 \\
\hline Caprolactam degradation & 7 & 7 & 0 & 1 & 0 & 0 & 0.0 & 0.0 & 0.0 \\
\hline SNARE interactions in vesicular transport & 38 & 38 & 1 & 1 & 0 & 0 & 0.0 & 0.0 & 0.0 \\
\hline Asthma & 30 & 30 & 1 & 1 & 0 & 0 & 0.0 & 0.0 & 0.0 \\
\hline Inositol metabolism & 2 & 2 & 0 & 0 & 0 & 0 & 0.0 & 0.0 & 0.0 \\
\hline Pentose and glucuronate interconversions & 25 & 22 & 0 & 0 & 0 & 0 & 0.0 & 0.0 & 0.0 \\
\hline Ascorbate and aldarate metabolism & 9 & 9 & 0 & 0 & 0 & 0 & 0.0 & 0.0 & 0.0 \\
\hline Fatty acid biosynthesis & 6 & 6 & 0 & 0 & 0 & 0 & 0.0 & 0.0 & 0.0 \\
\hline Fatty acid elongation in mitochondria & 10 & 10 & 0 & 0 & 0 & 0 & 0.0 & 0.0 & 0.0 \\
\hline Ubiquinone biosynthesis & 15 & 13 & 1 & 0 & 0 & 0 & 0.0 & 0.0 & 0.0 \\
\hline Caffeine metabolism & 7 & 7 & 0 & 0 & 0 & 0 & 0.0 & 0.0 & 0.0 \\
\hline Geraniol degradation & 11 & 11 & 0 & 0 & 0 & 0 & 0.0 & 0.0 & 0.0 \\
\hline Bisphenol A degradation & 5 & 5 & 0 & 0 & 0 & 0 & 0.0 & 0.0 & 0.0 \\
\hline Fluorobenzoate degradation & 1 & 1 & 0 & 0 & 0 & 0 & 0.0 & 0.0 & 0.0 \\
\hline $\begin{array}{l}\text { Phenylalanine, tyrosine and tryptophan biosyn- } \\
\text { thesis }\end{array}$ & 9 & 9 & 0 & 0 & 0 & 0 & 0.0 & 0.0 & 0.0 \\
\hline Novobiocin biosynthesis & 3 & 3 & 0 & 0 & 0 & 0 & 0.0 & 0.0 & 0.0 \\
\hline Taurine and hypotaurine metabolism & 10 & 10 & 0 & 0 & 0 & 0 & 0.0 & 0.0 & 0.0 \\
\hline Aminophosphonate metabolism & 17 & 17 & 0 & 0 & 0 & 0 & 0.0 & 0.0 & 0.0 \\
\hline Cyanoamino acid metabolism & 9 & 9 & 0 & 0 & 0 & 0 & 0.0 & 0.0 & 0.0 \\
\hline
\end{tabular}


222 Genomics \& Informatics Vol. 6(4) 210-222, December 2008

Supplementary Table S1. Continued

\begin{tabular}{|c|c|c|c|c|c|c|c|c|c|}
\hline \multirow{2}{*}{ KEGG Pathway Description } & \multirow{2}{*}{$\begin{array}{c}\text { \# of } \\
\text { genes in } \\
\text { pathway }\end{array}$} & \multirow{2}{*}{$\begin{array}{l}\text { \# of } \\
\text { genes } \\
\text { linked to } \\
\text { GPL570 } \\
\text { Probes }\end{array}$} & \multicolumn{2}{|c|}{$\begin{array}{c}\mathrm{p}<0.05 \\
\# \text { of Over } \\
\text { Expressed Genes }\end{array}$} & \multicolumn{2}{|c|}{$\begin{array}{c}\mathrm{p}<0.01 \\
\text { \# of Over } \\
\text { Expressed Genes }\end{array}$} & \multirow{2}{*}{ P1 } & \multirow{2}{*}{ P2 } & \multirow{2}{*}{ P3 } \\
\hline & & & $\begin{array}{l}\text { Lobular } \\
\text { Carci- } \\
\text { noma }\end{array}$ & $\begin{array}{l}\text { Ductal } \\
\text { Carci- } \\
\text { noma }\end{array}$ & $\begin{array}{l}\text { Lobular } \\
\text { Carci- } \\
\text { noma }\end{array}$ & $\begin{array}{l}\text { Ductal } \\
\text { Carci- } \\
\text { noma }\end{array}$ & & & \\
\hline D-Glutamine and D-glutamate metabolism & 4 & 4 & 1 & 0 & 0 & 0 & 0.0 & 0.0 & 0.0 \\
\hline D-Arginine and D-ornithine metabolism & 1 & 1 & 0 & 0 & 0 & 0 & 0.0 & 0.0 & 0.0 \\
\hline N-Glycan degradation & 16 & 16 & 0 & 0 & 0 & 0 & 0.0 & 0.0 & 0.0 \\
\hline Nucleotide sugars metabolism & 6 & 6 & 3 & 0 & 0 & 0 & 0.0 & 0.0 & 0.0 \\
\hline Streptomycin biosynthesis & 10 & 10 & 1 & 0 & 0 & 0 & 0.0 & 0.0 & 0.0 \\
\hline Peptidoglycan biosynthesis & 5 & 5 & 0 & 0 & 0 & 0 & 0.0 & 0.0 & 0.0 \\
\hline Tetrachloroethene degradation & 3 & 3 & 0 & 0 & 0 & 0 & 0.0 & 0.0 & 0.0 \\
\hline 1,4-Dichlorobenzene degradation & 1 & 1 & 0 & 0 & 0 & 0 & 0.0 & 0.0 & 0.0 \\
\hline Styrene degradation & 3 & 3 & 1 & 0 & 0 & 0 & 0.0 & 0.0 & 0.0 \\
\hline C5-Branched dibasic acid metabolism & 2 & 2 & 0 & 0 & 0 & 0 & 0.0 & 0.0 & 0.0 \\
\hline Methane metabolism & 7 & 7 & 0 & 0 & 0 & 0 & 0.0 & 0.0 & 0.0 \\
\hline Thiamine metabolism & 8 & 8 & 0 & 0 & 0 & 0 & 0.0 & 0.0 & 0.0 \\
\hline Vitamin B6 metabolism & 5 & 5 & 0 & 0 & 0 & 0 & 0.0 & 0.0 & 0.0 \\
\hline Biotin metabolism & 4 & 4 & 0 & 0 & 0 & 0 & 0.0 & 0.0 & 0.0 \\
\hline Lipoic acid metabolism & 2 & 2 & 0 & 0 & 0 & 0 & 0.0 & 0.0 & 0.0 \\
\hline Monoterpenoid biosynthesis & 2 & 2 & 0 & 0 & 0 & 0 & 0.0 & 0.0 & 0.0 \\
\hline Phenylpropanoid biosynthesis & 4 & 4 & 0 & 0 & 0 & 0 & 0.0 & 0.0 & 0.0 \\
\hline Alkaloid biosynthesis I & 5 & 5 & 0 & 0 & 0 & 0 & 0.0 & 0.0 & 0.0 \\
\hline \multirow[t]{2}{*}{ Circadian rhythm } & 13 & 13 & 0 & 0 & 0 & 0 & 0.0 & 0.0 & 0.0 \\
\hline & & & & & & Mean: & 0.9 & 2.1 & 1.5 \\
\hline
\end{tabular}

